\title{
Note: U-Pb baddeleyite dating clarifies age of characteristic paleomagnetic remanence of Long Range dykes, southeastern Labrador
}

\author{
Sandra L. Kamo ${ }^{1}$ and Charles F. Gower ${ }^{2}$ \\ 1 Jack Satterly Geochronology Laboratory, Royal Ontario Museum, \\ 100 Queen's Park, Toronto, Ontario M5S 2C6, Canada \\ ${ }^{2}$ Newfoundland Department of Natural Resources, Geological Survey Branch, \\ P.O. Box 8700, St. John's, Newfoundland A1B 4J6, Canada
}

Date Received December 23, 1994

Date Accepted February 16, 1995

\begin{abstract}
A second age of $615 \mathrm{Ma}$ has been obtained for the Long Range dykes in Labrador. This age removes uncertainty, introduced by anomalous paleomagnetic results, that more than one age of dykes trending north-northeast is present in the region. It also establishes that the age of the primary magnetization of the Long Range dykes is $615 \mathrm{Ma}$.

On a obtenu un deuxième âge, fixé à $615 \mathrm{Ma}$, par rapport aux dykes de Long Range, au Labrador. Celui-ci élimine l'incertitude, qu'avaient amenée des résultats paléomagnétiques anomaux, au sujet de la présence de dykes de Long Range d'une direction nord-nord-est de plus d'un âge dans la région. On a en outre établi l'âge de la magnétisation originelle des dykes de Long Range à $615 \mathrm{Ma}$.
\end{abstract}

[Traduit par la rédaction]

\section{INTRODUCTION}

This short study is a follow-up of the work of Kamo et al. (1989), who reported the age of a Long Range dyke in southeastern Labrador to be $615 \pm 2 \mathrm{Ma}$. The objective of this work is to resolve an uncertainty that arose as a result of subsequent paleomagnetic investigations (Murthy et al., 1992) on the same dykes. Of six dykes investigated by Murthy et al. (1992), three gave a remanence direction of $\mathrm{D}$ (declination) $=124.8^{\circ}$ and $\mathrm{I}$ (inclination) $=55.5^{\circ}$, interpreted to be primary on the basis of a positive baked contact test. Three other dykes, including the previously dated dyke, gave anomalous directions. It was, therefore, not completely certain that the interpreted primary remanence direction could be linked to the $615 \mathrm{Ma}$ age. The present investigation sought to resolve the doubt by dating another Long Range dyke, in this case from one of the localities where the interpreted primary remanence was obtained.

\section{SaMPling LOCALITY}

The locality investigated (Fig. 1, annotated as 'this paper') is Dyke 4 of Murthy et al. (1992) and was chosen for further geochronological study for two reasons. The first is that, from a paleomagnetic standpoint, it is the most thoroughly studied dyke in the area. It has been investigated at seven sites at various points along its length, all of which yielded a consistent remanence direction, averaging $\mathrm{D}=133.1^{\circ}, \mathrm{I}=51.2^{\circ}$. The second reason is that a K-Ar (biotite) age of $553 \pm 22 \mathrm{Ma}$ had been previously reported for the dyke (Wanless et al., 1970), although the location of the sample was erroneously reported to be farther west in the original publication, (W.D. Loveridge, personal communication to C.F. Gower, 1985).
The sample site is at the north end of an unnamed island and corresponds to the paleomagnetic sites PR84-191, PR84199, and PR84-206 (Fig. 1). The geographic co-ordinates are $53^{\circ} 46.2^{\prime} \mathrm{N}, 56^{\circ} 37.1^{\prime} \mathrm{W}$.

The sample selected for U-Pb geochronology is a coarsegrained olivine gabbro. Although in many Long Range dykes primary olivine is preserved, in this dyke it has been completely altered to serpentine and opaque minerals. Plagioclase forms euhedral, well-twinned, but moderately to extensively sericitized euhedral to subhedral laths. Primary clinopyroxene forms anhedral grains between plagioclase laths and olivine grains. Other primary minerals include biotite, apatite, zircon, baddeleyite and pyrite. Greenschist facies alteration is pervasive and, apart from the previously mentioned secondary minerals, clusters of fibrous amphibole are also present.

\section{GeOChronological RESULTS}

$\mathrm{U}-\mathrm{Pb}$ baddeleyite and zircon isotopic results are presented in Table 1 and Figure 2. All age errors quoted below and error ellipses in Figure 2 are given at the $95 \%$ confidence level. Errors in Table 1 are $1 \sigma$. Chemical decomposition of the grains and isolation of $\mathrm{Pb}$ and $\mathrm{U}$ was achieved using the method of Krogh (1973) modified for small samples by using miniaturized dissolution bombs and anion exchange columns. Details of the procedures used at the Jack Satterly Geochronology Laboratory are given by Heaman and Machado (1992).

Baddeleyite occurs as striated, brown, euhedral laths and plates. Many of the crystals exhibit pitted, frosty surfaces; however, care was taken to exclude this type of grain from the fractions analysed. Only clear, crack- and inclusion-free grains with shiny, smooth surfaces were selected for analysis. Zircon oc- 


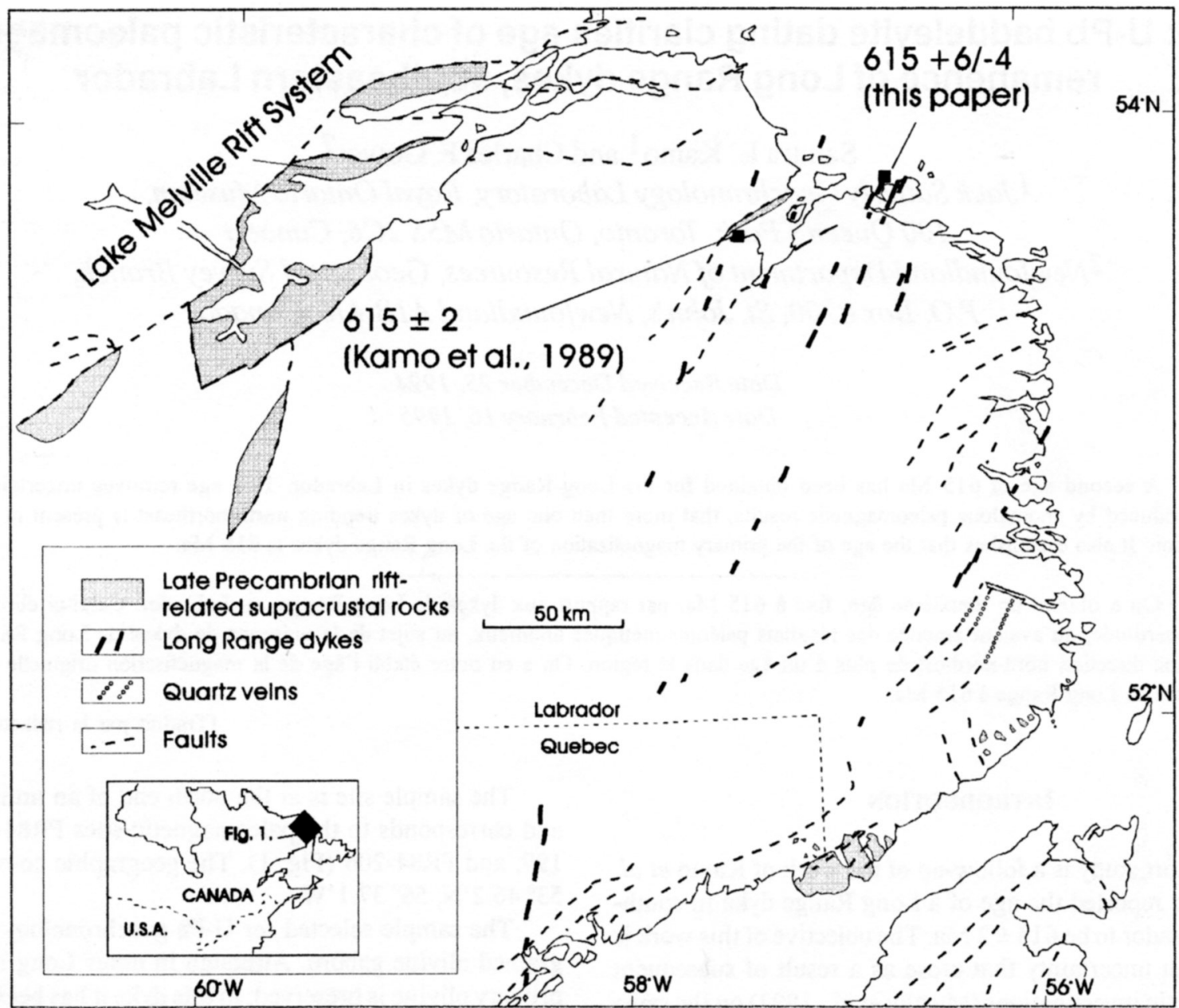

Fig. 1. Distribution of Long Range dykes, Neoproterozoic rift-related supracrustal rocks, brittle faults and associated quartz veins in southeast Labrador.

Table 1. U-Pb isotopic data for baddeleyite and zircon from a Long Range dyke, Labrador.

\begin{tabular}{|c|c|c|c|c|c|c|c|c|c|c|}
\hline Sample & $\begin{array}{c}\text { Weight } \\
\text { (mg) }\end{array}$ & $\begin{array}{c}U \\
(\mathrm{ppm})\end{array}$ & $\begin{array}{c}\mathrm{Pb} \\
(\mathrm{ppm})\end{array}$ & Th/Ua & $\begin{array}{c}\text { Common } \\
\mathrm{Pb}^{\mathrm{b}} \\
(\mathrm{pg})\end{array}$ & $\begin{array}{c}206 \mathrm{~Pb} / \mathrm{c} \\
204 \mathrm{~Pb}\end{array}$ & $\begin{array}{c}{ }^{206} \mathrm{~Pb} / \mathrm{d} \\
238_{U}\end{array}$ & $\begin{array}{c}{ }^{207} \mathrm{~Pb} / \mathrm{d} \\
{ }^{235} \mathrm{U}\end{array}$ & $\begin{array}{c}{ }^{207} \mathrm{~Pb} / \mathrm{d} \\
{ }^{206} \mathrm{~Pb}\end{array}$ & $\begin{array}{l}\text { Age }(\mathrm{Mc} \\
207 \mathrm{~Pb} / \\
206 \mathrm{~Pb}\end{array}$ \\
\hline ddeleyite (33) & 0.056 & 328 & 33 & 0.03 & 156 & 749 & $0.09932 \pm 10$ & $0.8256 \pm 19$ & $0.06029 \pm 12$ & 614.0 \\
\hline ddeleyite (17) & 0.030 & 234 & 21 & 0.03 & 10 & 4177 & $0.09860 \pm 19$ & $0.8184 \pm 15$ & $0.06020 \pm 7$ & 610.8 \\
\hline $\operatorname{rcon}(20)$ & 0.044 & 359 & 40 & 0.81 & 3 & 28557 & $0.09849 \pm 11$ & $0.8184 \pm 10$ & $0.06027 \pm 4$ & 613.2 \\
\hline rcon (17) & 0.042 & 567 & 72 & 1.38 & 6 & 22875 & $0.09753 \pm 16$ & $0.8099 \pm 14$ & $0.06023 \pm 3$ & 611.7 \\
\hline Iddeleyite (14) & 0.049 & 428 & 38 & 0.03 & 7 & 18935 & $0.09719 \pm 32$ & $0.8066 \pm 25$ & $0.06019 \pm 8$ & 610.5 \\
\hline
\end{tabular}

Notes: All samples selected from the least magnetic fractions separated using a Frantz magnetic separator $\left(0^{\circ}\right.$ forward and side tilt at $\left.1.7 \mathrm{~A}\right)$; numbe in brackets is number of grains or fragments in fraction; a, model $\mathrm{Th} / \mathrm{U}$ ratio is calculated using the amount of ${ }^{208} \mathrm{~Pb}$ and the ${ }^{207} \mathrm{~Pb} / 206 \mathrm{~Pb}$ age; $\mathrm{t}$ total common $\mathrm{Pb}$ present from sample and laboratory contributions; c, corrected for spike and fractionation; $d$, corrected for spike, fractionatio (0.10\%/AMU for $\mathrm{Pb}$ and $\mathrm{U}$ ), blank (2 pg Pb, $0.5 \mathrm{pg} \mathrm{U})$, and initial common $\mathrm{Pb}$. The isotopic composition of common $\mathrm{Pb}$ in the sample is calculate using the model of Stacey and Kramers (1975); errors on the ${ }^{206} \mathrm{~Pb} /{ }^{238} \mathrm{~Pb}$ and ${ }^{207} \mathrm{~Pb} /{ }^{206} \mathrm{~Pb}\left(\mathrm{x} 10^{-5}\right)$ and ${ }^{207} \mathrm{~Pb} /{ }^{235} \mathrm{U}\left(\mathrm{x} 10^{-4}\right)$ ratios are $1 \sigma$. 


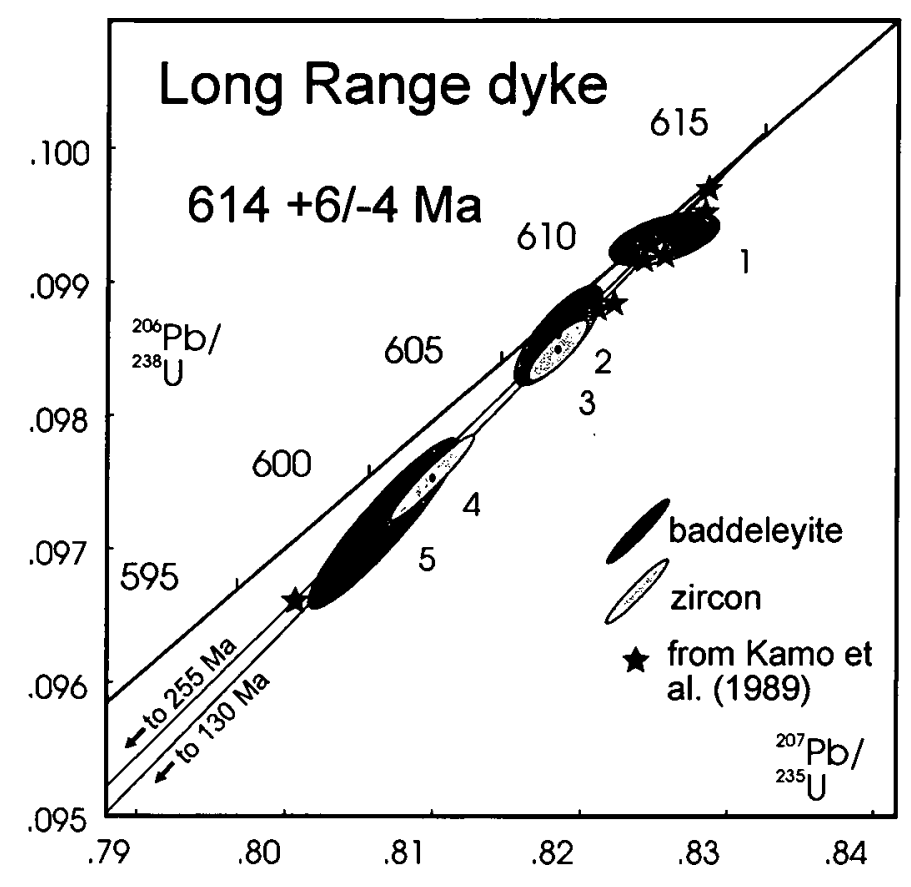

Fig. 2. Concordia diagram showing U-Pb results for the Long Range dyke dated in this study. Ellipses represent $2 \sigma$ errors. Data from Kamo et al. (1989) were obtained from zircon and baddeleyite and give a lower intercept of $c a$. $255 \mathrm{Ma}$.

curs as pale yellow, clear to hazy, skeletal fragments. Due to the platy habit of these minerals, no air abrasion treatment (Krogh, 1982) was given to any of the analysed fractions.

Data points obtained from three fractions of baddeleyite and two fractions of zircon range from 0.8 to $3.5 \%$ discordant. A regression calculation using all five data points yields an upper intercept age of $614+22 /-4 \mathrm{Ma}$. A lower intercept age of ca. $130 \mathrm{Ma}$ is also given. Due to the limited spread of these data points, it is useful to define the range in the upper intercept age by assuming that $\mathrm{Pb}$ loss occurred between 0 and 300 $\mathrm{Ma}$. In this case, an age of $614+6 /-4 \mathrm{Ma}$ is given, and this is considered a more reasonable upper age error given the consistency with concordant data (shown in Fig. 2) obtained previously by Kamo et al. (1989).

\section{Discussion}

Precise ages for mafic dykes are extremely valuable for continental plate reconstructions and for establishing the time of continental breakup, and these data also provide the critical information necessary for calibrating the apparent polar wander path. Unfortunately, previous U-Pb dating (Kamo et al., 1989) and paleomagnetic data (Murthy et al., 1992) for the Long Range dykes failed to give clear information on the Late Proterozoic polar wander path for North America.

The paleomagnetic data reported by Murthy et al. (1992) yielded anomalous results for which two explanations were offered: either (i) two dyke sets are present, or (ii) the 'anomalous' directions are not primary. Murthy et al. (1992) argued, from field, petrographic and chemical criteria, that only one dyke swarm is present and this conclusion is substantiated by the result reported here.
The new date is pertinent to the re-interpretation of Long Range dyke paleomagnetic signatures made by Meert et al. (1994). They argued that the 'anomalous' magnetization obtained by Murthy et al. (1992) from the dyke (Dyke 1) previously dated at $615 \pm 2$ Ma by Kamo et al. (1989) is the primary remanence direction. They also re-interpreted the magnetization that was regarded as primary by Murthy et al. (1992) as having been acquired at $c a$. $550 \mathrm{Ma}$, on the basis of the $553 \pm$ $22 \mathrm{Ma} \mathrm{K}$-Ar biotite age previously obtained from that dyke (Dyke 4). It is from this dyke that we report the $615+6 /-4 \mathrm{Ma}$ crystallization age.

If the remanence preserved in Dyke 4 is interpreted as secondary and linked to the time of K-Ar biotite closure, rather than the time of dyke crystallization, then the same approach should be applied to Dyke 1. At present no K-Ar ages are available from Dyke 1, but at the paleomagnetically sampled site Dyke 1 is intruded by Carboniferous mafic dykes from which a $\mathrm{K}$-Ar whole-rock age of $327 \pm 13 \mathrm{Ma}$ has been obtained (from a locality $3 \mathrm{~km}$ to the southeast; Murthy et al., 1989). For consistency, this would have to be the preferred age to which Meert $e t$ al. (1994) should have related the anomalous magnetization, rather than the $615 \mathrm{Ma} \mathrm{U}-\mathrm{Pb}$ age. However, Murthy et al. (1992) indicated that the anomalous magnetization was not a Carboniferous overprint.

Furthermore, if the remanence direction in Dyke 4 is to be considered secondary and acquired at $c a .550 \mathrm{Ma}$ then so must it be in Dykes 2 and 6 ( $35 \mathrm{~km}$ west and $75 \mathrm{~km}$ east of Dyke 4, respectively) and in the Double Mer Formation ( $200 \mathrm{~km}$ to the west), as similar results were obtained from all of these units. However, the occurrence of a significant regional thermal event at $c a$. $550 \mathrm{Ma}$ appears to be excluded by a baked contact test carried out adjacent to Dyke 2 (Murthy et al., 1992).

The data reported here confirm that there is no age difference between the two paleomagnetic groups and that the previously interpreted primary remanence direction can, indeed, be referred to a $615 \mathrm{Ma}$ age. The 'anomalous' group, which included the dyke previously dated at $615 \pm 2 \mathrm{Ma}$, therefore presumably represents disturbed data.

It should be noted that red beds from the Double Mer Formation in the Lake Melville rift system (Fig. 1) carry a remanence direction that is, within error, the same as that in the dyke dated in this study. Hence, the date gives quantitative confirmation of a Late Precambrian depositional age for the Double Mer Formation. Finally, the data here also establish that the KAr age of $553 \mathrm{Ma}$ does not date the time of emplacement of the dyke, but is related to a younger event.

\section{ACKNOWLEDGEMENTS}

Helpful reviews given by K. Buchan and J. David are gratefully acknowledged.

Heaman, L.H. and Machado, N. 1992. Timing and origin of midcontinent rift alkaline magmatism, North America: evidence from the Coldwell complex. Contributions to Mineralogy and Petrology, 110, pp. 289-303.

Kamo, S., Gower, C.F., and Krogh, T.E. 1989. A birthdate for the Iapetus ocean? A precise $\mathrm{U}-\mathrm{Pb}$ zircon and baddeleyite age for the Long Range dykes, S.E. Labrador. Geology, 17, pp. 602-605. 
KROGH, T.E. 1973. A low-contamination method for hydrothermal decomposition of zircon and extraction of $\mathrm{U}$ and $\mathrm{Pb}$ for isotope age determinations. Geochimica et Cosmochimica Acta, 37, pp. 485494.

1982. Improved accuracy of U-Pb zircon ages by the creation of more concordant systems using an air abrasion technique. Geochimica et Cosmochimica Acta, 46, pp. 637-649.

Meert, J.G., VAN der Voo, R., and PaYNe, T.W. 1994. Paleomagnetism of the Catoctin volcanic province: a new Vendian-Cambrian apparent polar wander path for North America. Journal of Geophysical Research, 99, B3, pp. 4625-4641.
Murthy, G., Gower, C., Tubrett, M., and Patzold, R. 1992. Paleomagnetism of Eocambrian Long Range dykes and Double Mer Formation from Labrador, Canada. Canadian Journal of Earth Sciences, 29, pp. 1224-1234.

StaceY, J.S. and Kramers, J.D. 1975. Approximation of terrestrial lead isotope evolution by a two-stage model. Earth and Planetary Science Letters, 26, pp. 207-221.

Wanless, R.K., Stevens, R.D., Lachance, G.R., and Delabio, R.N. 1970. Age determinations and geological studies. Geological Survey of Canada, Paper 69-2A, Report 9, 78 p. 